\title{
Effects of sustainable land management interventions on selected soil properties in Geda watershed, central highlands of Ethiopia
}

\author{
Hailu Terefe ${ }^{1 *}\left(\mathbb{D}\right.$, Mekuria Argaw ${ }^{1}$, Lulseged Tamene ${ }^{2}$, Kindu Mekonnen $^{3}$, John Recha ${ }^{4}$ and Dawit Solomon ${ }^{3}$
}

\begin{abstract}
Background: Land degradation through soil erosion by water is severe in the highlands of Ethiopia. In order to curb this problem, the government initiated sustainable land management interventions in different parts of the country since 2008, and in Geda watershed since 2012. However, the impacts of the interventions on soil properties were not assessed so far. Thus, this study investigated the impacts of sustainable land management interventions on selected soil properties in Geda watershed. Soil samples were collected from treated and untreated subwatersheds at the upper and lower landscape positions, from cropland and grazing lands at two soil depths (0-15 $\mathrm{cm}$ and $15-30 \mathrm{~cm}$ ). Selected soil physicochemical properties were assessed with respect to landscape position, land-use type, and soil depth in both treated and untreated sub-watersheds.

Results: Generally, most of the soil physicochemical properties differed greatly across sub-watersheds, land-use types, and soil depths. Clay, electrical conductivity, total N, available P, exchangeable K, and organic carbon were higher in the treated sub-watershed, whereas sand, silt, bulk density, and pH were higher in the untreated subwatershed. The higher sand, silt, and bulk density could be attributed to erosion, while the higher pH could be due to the higher exchangeable $\mathrm{Na}$ in the untreated sub-watershed. Most of the selected soil chemical properties were not affected by landscape position, but land-use type affected available $P$ and organic carbon with higher mean values at croplands than at grazing lands, which could be ascribed to the conservation structure and tillage of the soils in that conservation structures trap and accumulate transported organic materials from the upper slope, while tillage facilitates aeration and decomposition processes.
\end{abstract}

Conclusion: Sustainable land management interventions improved soil physicochemical properties and brought a positive restoration of the soil ecosystem. Maintaining the soil conservation measures and enhancing community awareness about the benefits, coupled with management of livestock grazing are required to sustain best practices.

Keywords: Crop-livestock system, Land degradation, Land-use type, Sub-watershed, Soil depth

\section{Background}

Land degradation is one of the major global challenges of the twenty-first century that threatens environmental conservation and sustainable development (Gashaw et al. 2014; Ebabu et al. 2017). Globally, nearly 5.0 billion ha (about $43 \%$ of the Earth's vegetated surface) has been

\footnotetext{
* Correspondence: terefehailu@gmail.com

${ }^{1}$ Center for Environmental Science, College of Natural Science, Addis Ababa

University, P.O. Box 1176, Addis Ababa, Ethiopia

Full list of author information is available at the end of the article
}

degraded through soil erosion due to the deterioration of dryland vegetation and tropical moist forests; among which the tropics share 2.1 billion ha (Gebretsadik 2013; Gashaw 2015). Currently, the rate of global land degradation is 10 to 12 million ha year ${ }^{-1}$ (Thomas et al. 2018). The problem of land degradation has undermined development efforts in agricultural productivity and hinders environmental sustainability in many countries (Berhanu et al. 2016; Ademe et al. 2017). 
Soil erosion affects half of Ethiopia's agricultural land and results in a soil loss rate of 35 to $42 \mathrm{t} \mathrm{ha}^{-1}$ year $^{-1}$ and a monetary value of US\$1 to 2 billion year ${ }^{-1}$ (Dessalegn et al. 2015). Ayalew (2011) reported that $17 \%$ of the potential annual agricultural income was lost due to physical and biological soil degradation. In addition, soil degradation brings about indirect costs such as loss of environmental services, silting of dams and river beds, reduced groundwater, and social and community losses due to malnutrition and poverty. It is estimated that the cost of land degradation in Ethiopia reaches $23 \%$ of the country's GDP (Kirui and Mirzabaev 2015).

To curb this severe land degradation, the government of Ethiopian launched massive rehabilitation programs starting from the mid-1970s (Ebabu et al. 2017; Adimassu et al. 2017). It is estimated that more than 1 billion US dollars were invested during the years of 19741991. In addition, more than 500 million US dollars have been invested in the Productive Safety Net Program since 2005, and huge financial resources have been invested in the Sustainable Land Management Program (SLMP) since 2008 for soil and water conservation (SWC) practices (Adimassu et al. 2017). Due to the low success rate of restoration works done between 1976 and 1990 (Gashaw 2015), the approach of rehabilitation works was modified to integrate watershed-based interventions as of the 1980s (Ebabu et al. 2017; Gashaw et al. 2017), which has been extensively implemented by the government and non-government organizations.

The assumption of the watershed-based intervention approach was that the local communities would take part as major actors in the process of watershed-based rehabilitation activities (Haregeweyn et al. 2012). Accordingly, different research programs and national and international organizations contributed their part to implement and promote SWC and sustainable land management (SLM) options across different catchments and watersheds in Ethiopia (Mekuria et al. 2011; Haregeweyn et al. 2012; Ebabu et al. 2017). However, comparative studies on the effects of these interventions at watershed levels are limited in the country. Few studies, such as Mulugeta and Karl (2010) in Farta district, Amhara Region; Hishe et al. (2017) in the Middle Silluh Valley of Tigray Region; Ademe et al. (2017) in the Wonago district of Southern Nations, Nationalities, and Peoples' Region; and Tufa et al. (2019) at Kuyu district in Oromiya Region, have been undertaken and showed improvements of selected soil properties at the conserved landscapes relative to the nonconserved ones. These studies took place in different agroecological zones, and therefore, this study assessed the effects of SLM interventions on selected soil physicochemical properties by comparing adjacent subwatersheds, whereby one had SLM measures and another did not have, in Geda watershed, Amhara Region.

\section{Materials and methods}

\section{Description of the study area}

The study was conducted in Geda watershed, North Shewa Zone of Amhara National, Regional State, Ethiopia, geographically located in a Blue Nile basin between $39^{\circ} 40^{\prime} 40^{\prime \prime}$ and $39^{\circ} 41^{\prime} 20^{\prime \prime}$ east longitude and $9^{\circ}$ $48^{\prime} 40^{\prime \prime}$ and $9^{\circ} 49^{\prime} 20^{\prime \prime}$ north latitude (Fig. 1). The watershed has a catchment area of 1056 ha within Gudo Beret and Adisgie villages (Tamene et al. 2015), situated in a highland agroecological zone with an elevation of 2865 to 3105 masl. The watershed receives an average annual rainfall of $1277.8-2061.3 \mathrm{~mm}$, and daily minimum temperature is within the range of 0.5 to $19.5^{\circ} \mathrm{C}$. The maximum daily temperature ranges from 9.5 to $28.5^{\circ} \mathrm{C}$ (Tamene 2017). Rainfall in the study area is bimodal: short rainy season falls between February and April, and heavy rainy season is between mid-June and mid-September.

Geologically, the site is characterized by volcanic rocks such as rhyolites, trachites, tuffs, and basalts. The major soils are andosol in the upper parts of the watershed, fluvisol at the valley bottoms, regosol at the eroded parts, and liptosol on steep slope areas (Ashagrie 2009; Amare et al. 2013). The watershed is characterized by the croplivestock mixed farming system with more lands allocated for crop production and grazing, while few plots, especially at the degraded and mountainous areas, are planted with eucalyptus trees. There is severe land degradation mainly in terms of soil erosion on higher slopes of the watershed.

In order to rehabilitate the degraded landscape, different conservation measures have been implemented on one side of Geda watershed since 2012 while the other part was not treated at all. Currently, the untreated subwatershed is under intensive crop production growing mainly barley, wheat, faba bean, and field pea during the wet season (June to September). After the crop is harvested in mid-October, livestock start grazing on stubbles and at the plot margins. After the harvesting time, each farmer transports the produce and hay to homesteads as quickly as possible in order to protect it from livestock damage in the field when free gazing starts. Then, the area is left for free grazing from November to mid-June until tillage for the next season's crop planting will take place. Cattle, sheep, donkeys, and horses freely graze in the sub-watershed for about 8 months, leaving hardly any soil cover on the landscape, and the cycle continues each year.

The other sub-watershed was treated by various SLM intervention options. Major SLM options practiced at the treated sub-watershed include soil bunds, also soil bunds supported by biological interventions mainly with tree lucerne (Chamaecytisus palmensis) and Phalaris (Phalaris acquatica, Phalaris arundinacea), percolation 


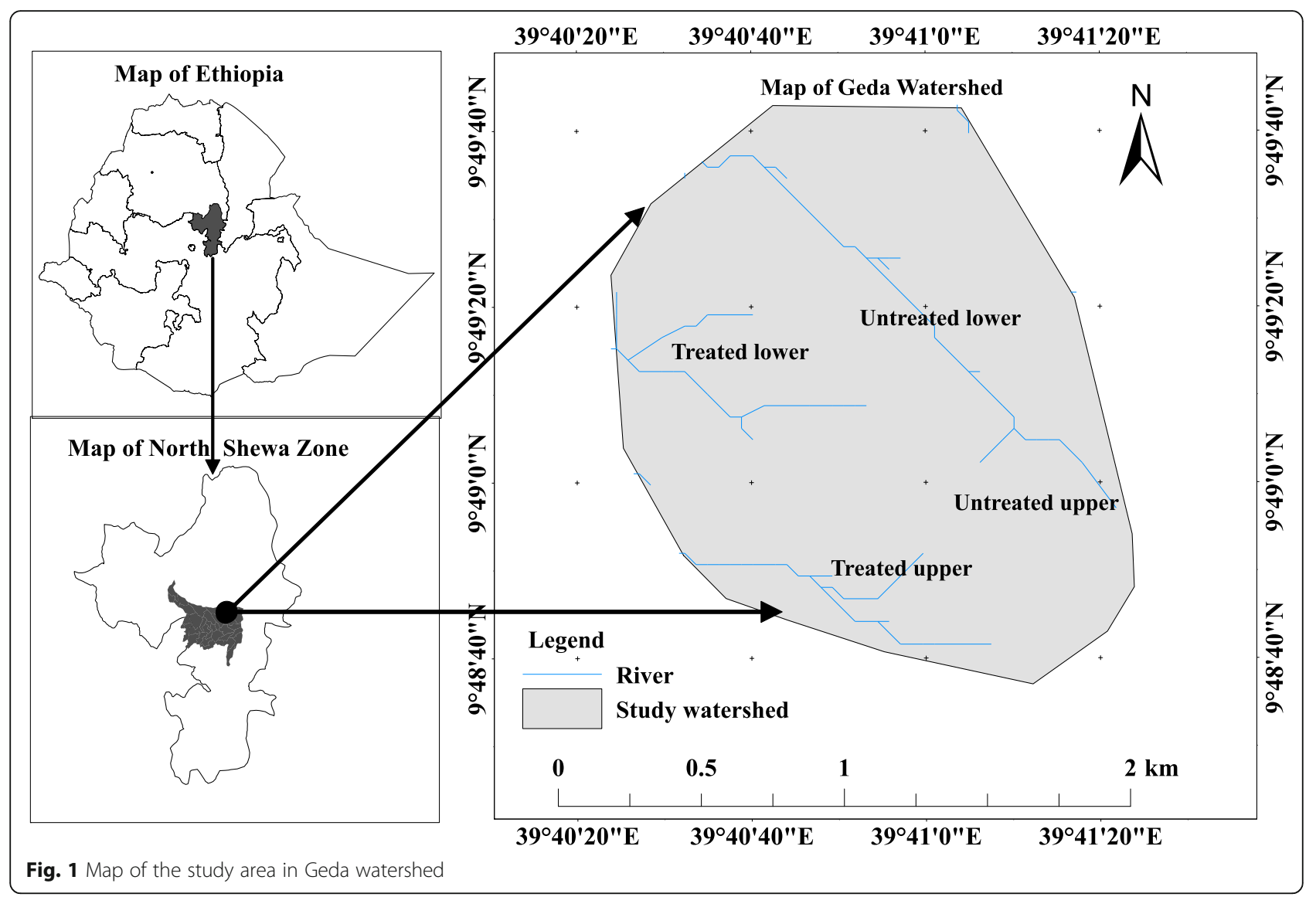

pits and water collecting ditches, tree lucerne plantations on highly degraded sections of the landscape, and the prohibition of free grazing. The SLM interventions covered more than $80-\mathrm{km}$ soil bund with trenches, $71 \mathrm{~m}^{3}$ of gabion check dam, $730-\mathrm{m}^{3}$ wood check dams, 19 percolation pits and some area closures with grass, and tree lucerne vegetation on highly degraded plots (Tamene 2017). The size of the treated sub-watershed from which data was collected was about 110 ha while the untreated sub-watershed was about 100 ha.

\section{Soil samples collection}

We followed the judgment sampling method (USEPA (United State Environmental Protection Agency) 2002) to locate representative sampling sites for both treated and control sub-watersheds, landscape positions (upper (3031-3156 masl) and lower (2947-3024 masl)), and land-use types (crop and grazing) at two soil depths (0$15 \mathrm{~cm}$ and 15-30 cm) (Wolka et al. 2011; Mekuria et al. 2018). Consequently, a total of 48 samples were collected $(2$ sub-watersheds $\times 2$ landscape positions $\times 2$ land uses $\times 2$ depths $\times 3$ replications).

In order to maximize plots uniformity, fields planted with cereal crops such as barley and wheat were purposely selected. Soil samples were collected using an Edelman auger (Tor-Gunnar et al. 1999) following a triangular sampling pattern. Samples were collected at five sampling points per plot and mixed to make a composite sample (Paetz and Wilke 2005; Wolka et al. 2011). After thoroughly mixing point samples, about $1 \mathrm{~kg}$ composite sample was packed in a plastic bag and taken to the laboratory for analysis (Paetz and Wilke 2005; Hishe et al. 2017). For the determination of bulk density, undisturbed soil samples were taken using a core sampler having a 5 - $\mathrm{cm}$ height and a $5-\mathrm{cm}$ diameter (volume $=98.125 \mathrm{~cm}^{3}$ ) (Masebo et al. 2014). Samples were analyzed in the Debre Berhan Agricultural Research Center laboratory.

\section{Soil analysis}

Soil samples were air-dried in the laboratory, crushed, and sieved by a $2-\mathrm{mm}$ mesh sieve (Descheemaeker et al. 2006). They were passed through a $0.5-\mathrm{mm}$ diameter sieve to prepare them for organic carbon (OC) and total nitrogen (TN) analysis. Particle size distribution, $\mathrm{pH}$, electrical conductivity (EC), exchangeable sodium (Ex.Na), exchangeable potassium (Ex.K), available phosphorus (Av.P), TN, and OC were determined following standard procedures and methods. 
Particle size analysis (\% sand, clay, silt) was carried out using the hydrometer procedure (van Reeuwijk 2002); $\mathrm{EC}(\mathrm{dS} / \mathrm{m})$ and $\mathrm{pH}(\mathrm{pH}$ meter) were measured in a 1:2.5 soil/water suspension (Tor-Gunnar et al. 1999; Descheemaeker et al. 2006); exchangeable cations ( $\mathrm{Na}$ and $\mathrm{K}$ ) were analyzed by adding 1-M ammonium acetate solution at pH 7 (Rowell 1994; Haldar and Sakar 2005); available $\mathrm{P}$ was determined following Olsen's extraction method (Olsen et al. 1954); TN was determined following Kjeldahl procedure as described in Wilke (2005); OC was done based on the Walkley-Black (Tor-Gunnar et al. 1999) rapid titration method. Bulk densities of the soils were determined from the mass of oven-dried soil at $105^{\circ} \mathrm{C}$ for $24 \mathrm{~h}$ and volume of the core sampler (Masebo et al. 2014; Tiki et al. 2016) through dividing the oven-dry mass by the volume of the core sampler (Wilke 2005; Alemayehu and Fisseha 2018).

\section{Statistical analysis}

Analysis of variance (ANOVA) was used to evaluate treatment effects on selected soil physical and chemical properties. Four ways ANOVA: SLM practice, landscape position, land use, and soil depth having two levels each, were performed using the General Linear Model of SAS version 9.4 statistical software (SAS Institute, 2016). Least significant differences and Duncan's mean separation at $P \leq 0.05$ were used to separate treatment means when there was a significant treatment effect using the LSMEANS procedure. Excel was used to make bar graphs.

\section{Results}

Effects of SLM interventions on soil physical properties

ANOVA revealed highly significant differences $(P \leq$ 0.001) for sand at sub-watersheds, landscape positions, and soil depths; for clay at sub-watersheds; for silt at landscape positions; and for bulk density at subwatersheds and landscape positions. Statistical differences $(P \leq 0.05)$ were observed for clay and bulk density at soil depths (Table 1).

Furthermore, the interaction effects of land uses on soil physical characteristics showed statistical differences (Table 2). In the upper landscape position of the untreated sub-watershed, both crop and grazing lands showed higher sand contents of $53.17 \%$ and $51.50 \%$, respectively, whereas, at the lower landscape, both landuse types showed higher silt content of $35.50 \%$ each. Clay content was higher at both land-use types in the treated sub-watershed. Regarding soil depths, a higher mean value of $55.83 \%$ sand was observed at $0-15-\mathrm{cm}$ depth in the upper landscape position, while a higher mean value of $37.67 \%$ silt was recorded at the subsurface 15-30-cm depth of the lower part of the untreated subwatershed. Furthermore, Duncan's mean separation revealed the highest bulk density of $1.36 \mathrm{~g} \mathrm{~cm}^{-3}$ at the
Table 1 Main effects of sub-watersheds, landscape positions, and soil depths on selected soil physical properties

\begin{tabular}{|c|c|c|c|c|}
\hline & \multirow{2}{*}{$\begin{array}{l}\mathrm{BD} \\
(\mathrm{g} / \\
\left.\mathrm{cm}^{3}\right)\end{array}$} & \multicolumn{3}{|c|}{ Particle size distribution (\%) } \\
\hline & & Sand & Clay & Silt \\
\hline \multicolumn{5}{|l|}{ Sub-watershed (SW) } \\
\hline Untreated sub-watershed & $1.26^{\mathrm{a}}$ & $46.63^{\mathrm{a}}$ & $22.58^{b}$ & 30.79 \\
\hline Treated sub-watershed & $1.07^{b}$ & $31.38^{b}$ & $36.92^{a}$ & 31.71 \\
\hline \multicolumn{5}{|l|}{ Landscape position (LP) } \\
\hline Upper & $1.22^{\mathrm{a}}$ & $41.75^{\mathrm{a}}$ & 29.46 & $28.79^{b}$ \\
\hline Lower & $1.12^{\mathrm{b}}$ & $36.25^{b}$ & 30.04 & $33.71^{a}$ \\
\hline \multicolumn{5}{|l|}{ Soil depth (SD) } \\
\hline $0-15 \mathrm{~cm}$ & $1.20^{\mathrm{a}}$ & $41.21^{\mathrm{a}}$ & $28.23^{b}$ & 30.17 \\
\hline $15-30 \mathrm{~cm}$ & $1.14^{b}$ & $36.79^{b}$ & $30.88^{a}$ & 32.33 \\
\hline P-SW & $* * *$ & $* * *$ & $* * *$ & ns \\
\hline$P-L P$ & $* * *$ & $* * *$ & ns & $* * *$ \\
\hline P-SD & * & $* * *$ & * & ns \\
\hline
\end{tabular}

Means within columns under each topic followed by different letters are significantly different from each other at $P \leq 0.05$; ${ }^{*}$ significant at $P \leq 0.05$; ***significant at $P \leq 0.001$; $n$ s non-significant, $B D$ bulk density

surface $0-15$-cm soil depth in the upper part of the untreated sub-watershed (Table 2).

Interaction effects revealed that both croplands and grazing lands in the upper part of the untreated subwatershed showed significantly higher $(P \leq 0.001)$ bulk density. Clay content was higher at both land-use types and soil depths at both landscape positions in the treated sub-watershed (Table 2). In addition, a balanced distribution of soil particles was observed at both landscape positions at the treated sub-watershed (Fig. 2). Furthermore, we found a strong positive correlation $(r=0.837)$ between bulk density and sand content, whereas strong negative correlation $(r=-0.679)$ between bulk density and clay (Table 3).

\section{Effects of SLM interventions on selected soil chemical properties}

There were significant differences for selected soil chemical properties at sub-watersheds and soil depths at $P \leq$ 0.05; furthermore, statistical differences were observed for exchangeable $\mathrm{K}$ at landscape positions, for available $\mathrm{P}$, and $\mathrm{OC}$ at land-use types (Table 4).

According to Duncan's homogeneity test, significantly higher values were observed in the treated subwatershed for EC, TN, Av.P, Ex.K, and OC, but $\mathrm{pH}$ showed significantly higher values at the untreated subwatershed. There were significant differences for Ex.K at sub-watersheds, landscape positions, and soil depths, but land-use types did not show significant differences for Ex.K. Statistically higher mean value of $0.54 \%$ Ex.K was observed in the treated sub-watershed than the mean value of $0.44 \%$ of the untreated sub-watershed. 
Table 2 Interaction effects of sub-watersheds, landscape positions, land uses, and soil depths on selected soil physical properties

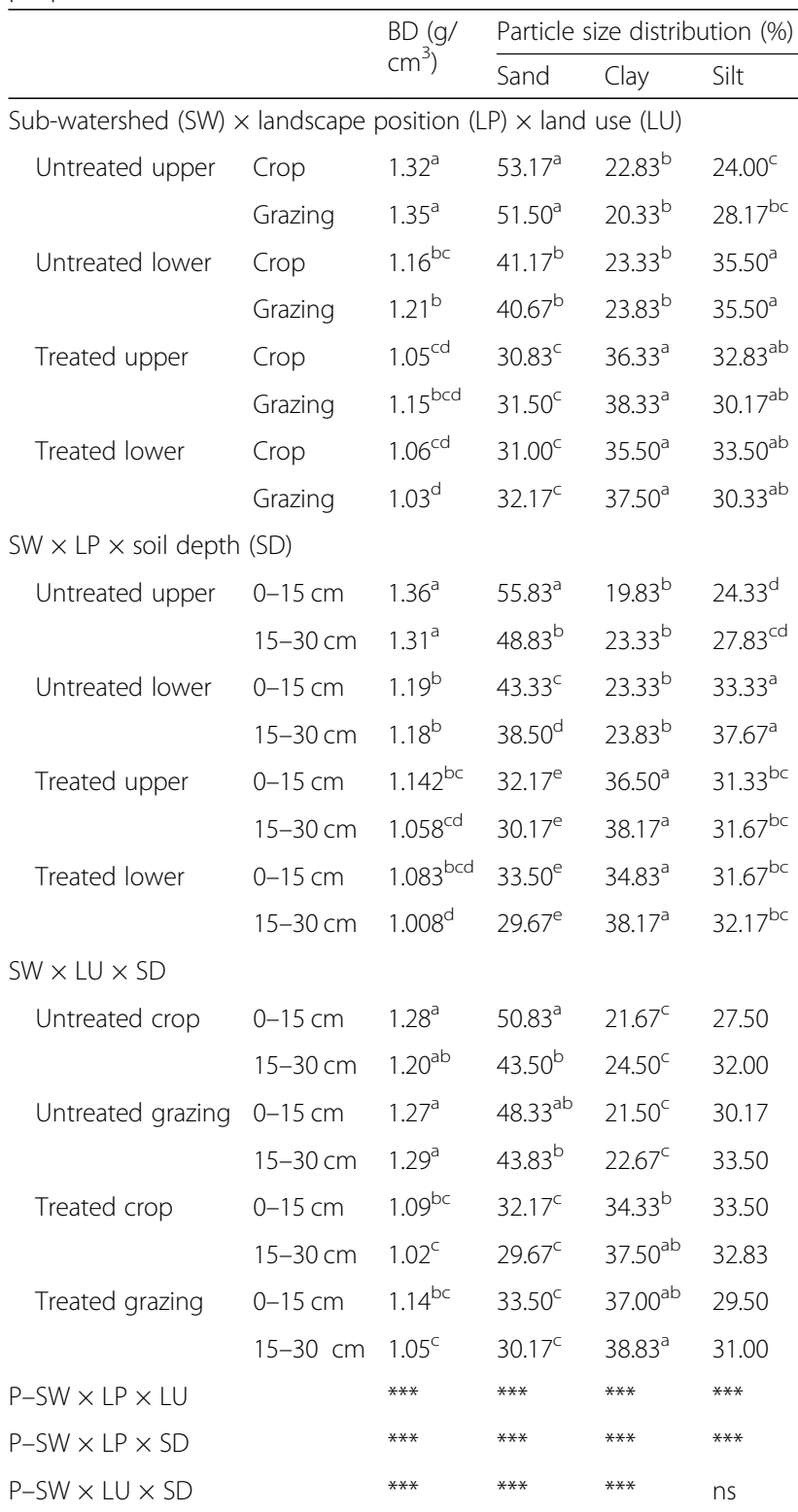

Means within columns under each subtopic followed by different letters are significantly different from each other at $P \leq 0.05$; ${ }^{* * *}$ significant at $P \leq 0.001$; $n$ s non-significant, $B D$ bulk density

Moreover, Ex.K showed statistically higher mean values of $0.57 \%$ and $0.56 \%$ at the lower landscapes and the top 0-15-cm depth, respectively.

Interaction effects of sub-watersheds with landscape positions, land-use types, and soil depths also showed significant differences in soil chemical properties except for $\mathrm{pH}$ at the sub-watershed by land-use interaction (Table 5).

Significantly higher mean values were observed for $\mathrm{pH}$ and Ex.Na in the untreated sub-watershed at both landscape positions. Soil pH and Ex.Na were not affected by land-use types. EC, TN, and Av.P were significantly higher at both landscape positions in the treated sub-watershed. TN was not affected by land-use types and landscape positions, but for Av.P, a higher mean value was observed in the cropland for Av.P in the treated sub-watershed.

The mean values of Ex.K and OC were significantly higher at the lower parts of the treated sub-watershed. Furthermore, land-use types did not affect EC, pH, TN, Ex.K, and $\mathrm{OC}$ at both sub-watersheds, whereas significantly higher mean value was observed for Av.P in the cropland than in the grazing land in the treated sub-watershed.

Regarding the sub-watershed by soil depth interactions, statistically higher mean values were observed for $\mathrm{pH}$ and Ex.Na in the untreated sub-watershed at the surface $0-15-\mathrm{cm}$ soil depth compared with the subsurface 15-30-cm depth and all depths in the treated subwatershed. Furthermore, statistically higher mean values were observed for TN, Av.P, Ex.K, and OC in the treated sub-watershed at the surface 0-15-cm depth compared with its subsurface $15-30-\mathrm{cm}$ depths and all depths at the untreated sub-watershed.

Significantly lower mean value of 5.94 was observed for $\mathrm{pH}$ at the upper part of the treated sub-watershed, and a statistically higher mean value of 6.44 was detected at the surface $0-15-\mathrm{cm}$ soil depth in the untreated subwatershed. The higher mean values of $\mathrm{pH}$ at the untreated sub-watershed could be attributed to the higher exchangeable sodium present at this sub-watershed. Ex.Na showed a statistically higher mean value of 0.522 at the surface $0-15-\mathrm{cm}$ depth of the untreated subwatershed and the lowest mean value of 0.388 at the subsurface $15-30-\mathrm{cm}$ depth in the treated subwatershed. TN showed the highest mean value of 0.122 at the surface $0-15-\mathrm{cm}$ depth in the treated subwatershed and the lowest mean value of 0.045 at the subsurface $15-30-\mathrm{cm}$ depth in the untreated subwatershed; likewise, Av.P, Ex.K, and OC showed the highest mean values of $13.31,0.59$, and 1.18 , respectively, on the surface $0-15-\mathrm{cm}$ depths in the treated subwatershed and the lowest mean values of 5.47, 0.36, and 0.323 , respectively, at the subsurface $15-30-\mathrm{cm}$ depth in the untreated sub-watershed (Table 5).

\section{Discussion}

\section{Particle size distribution}

The higher sand and silt contents in the upper and lower landscape positions in the untreated sub-watershed could be due to the removal of the fine particles from the upper part by soil erosion, leaving heavier sand particles behind, while the silts are deposited at the lower slope of the sub-watershed. On the other hand, higher clay fraction at the upper landscape in the treated subwatershed could be due to the establishment of conservation structures in the treated sub-watershed that 


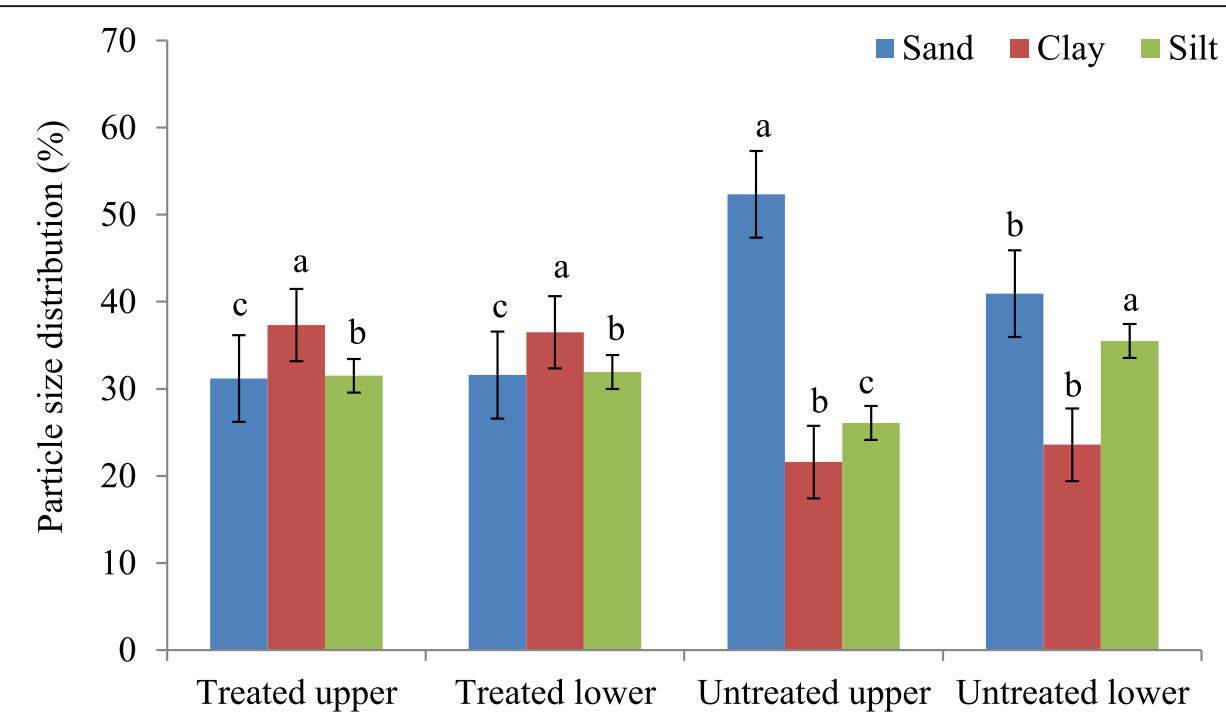

Fig. 2 Particle size distribution by sub-watersheds and landscape positions. Bars with different letters are significantly different for each soil particle

protected soil particles from erosive runoff and trapped them for in situ deposition (Wolka et al. 2011; Adimassu et al. 2014). Besides, the proportion of soil particles was relatively well balanced in the treated sub-watershed than the untreated sub-watershed (Fig. 2).

In the treated sub-watershed, in situ conservation of soil particles could contribute to the balanced proportion of sand, clay, and silt. Moreover, organic matter inputs from the decomposition of supportive biological interventions such as tree lucerne and Phalaris grass could contribute to the increase in the clay content of the soils. More stubble and grass remain in the fields since free grazing is prohibited in the treated subwatershed, whereas these organic sources are continuously exported from the fields in the untreated subwatershed through free grazing, making the soil poorer in clay contents.

Furthermore, the surface soil of cropland showed lower clay content than the subsurface soil in the treated sub-watershed. This could be attributed to the preferential removal of clay particles and its downward

Table 3 Pearson correlation coefficients, $N=48$ Prob $>|r|$ under $\mathrm{HO}: \mathrm{Rho}=0$

\begin{tabular}{lllll}
\hline & BD & Sand & Clay & Silt \\
\hline Sand & 0.837 & 1 & & \\
& $<0.0001$ & & & \\
Clay & -0.679 & -0.837 & 1 & \\
& $<0.0001$ & $<0.0001$ & & 1 \\
Silt & -0.512 & -0.573 & 0.031 & \\
& 0.0002 & $<0.0001$ & 0.835 & \\
\hline
\end{tabular}

Table 4 Main effects of sub-watersheds, landscape positions, land-use types, and soil depths on selected soil chemical properties

\begin{tabular}{|c|c|c|c|c|c|c|}
\hline & EC & $\mathrm{pH}$ & TN & Av.P & Ex.K & OC \\
\hline \multicolumn{7}{|c|}{ Sub-watershed (SW) } \\
\hline Untreated & $0.046^{b}$ & $6.30^{\mathrm{a}}$ & $0.063^{b}$ & $6.23^{b}$ & $0.44^{\mathrm{b}}$ & $0.42^{b}$ \\
\hline Treated & $0.063^{\mathrm{a}}$ & $6.11^{b}$ & $0.107^{a}$ & $11.12^{\mathrm{a}}$ & $0.54^{\mathrm{a}}$ & $0.98^{\mathrm{a}}$ \\
\hline \multicolumn{7}{|c|}{ Landscape position } \\
\hline Upper & 0.056 & 6.16 & 0.078 & 8.79 & $0.41^{\mathrm{b}}$ & 0.68 \\
\hline Lower & 0.053 & 6.24 & 0.092 & 8.56 & $0.57^{\mathrm{a}}$ & 0.72 \\
\hline \multicolumn{7}{|l|}{ Land use } \\
\hline Crop & 0.054 & 6.23 & 0.091 & $9.84^{\mathrm{a}}$ & 0.48 & $0.76^{a}$ \\
\hline Grazing & 0.055 & 6.17 & 0.079 & $7.51^{\mathrm{b}}$ & 0.50 & $0.65^{b}$ \\
\hline \multicolumn{7}{|l|}{ Soil depth } \\
\hline $0-15 \mathrm{~cm}$ & $0.047^{b}$ & $6.33^{\mathrm{a}}$ & $0.102^{a}$ & $10.15^{a}$ & $0.56^{\mathrm{a}}$ & $0.85^{\mathrm{a}}$ \\
\hline $15-30 \mathrm{~cm}$ & $0.062^{a}$ & $6.07^{b}$ & $0.068^{b}$ & $7.20^{\mathrm{b}}$ & $0.42^{\mathrm{b}}$ & $0.56^{b}$ \\
\hline P-SW & $* * *$ & $* *$ & $* * *$ & $* * *$ & ** & $* * *$ \\
\hline P-LP & ns & ns & ns & ns & $* * *$ & ns \\
\hline$P-L U$ & ns & ns & ns & $* * *$ & ns & * \\
\hline P-SD & * & $* * *$ & $* *$ & $* * *$ & $* * *$ & $* * *$ \\
\hline
\end{tabular}

Interaction means under each heading within columns followed by different letter(s) are significantly different from each other at $P \leq 0.05$; ${ }^{*}$ significant at $P \leq 0.05$; ${ }^{*}$ significant at $P \leq 0.01$; ${ }^{* * *}$ significant at $P \leq 0.001$; ns non-significant, $E C$ electrical conductivity $\left(\mathrm{dS} \mathrm{m}^{-1}\right), \mathrm{pH}$ soil reaction (pH meter), $T N$ total nitrogen, Av.P available phosphorus (PPM), Ex.K exchangeable potassium (\%), OC organic carbon (\%) 
Table 5 Interaction effects of sub-watersheds with landscape positions, land uses, and soil depths on selected soil chemical properties

\begin{tabular}{|c|c|c|c|c|c|c|c|}
\hline & EC & $\mathrm{pH}$ & TN & Av.P & Ex.K & OC & Ex.Na \\
\hline \multicolumn{8}{|c|}{ Sub-watershed (SW) $\times$ landscape position (LP) } \\
\hline Untreated upper & $0.049^{\mathrm{ab}}$ & $6.40^{\mathrm{a}}$ & $0.059^{b}$ & $6.06^{\mathrm{b}}$ & $0.36^{c}$ & $0.442^{c}$ & $0.468^{\mathrm{a}}$ \\
\hline Untreated lower & $0.043^{b}$ & $6.20^{\mathrm{a}}$ & $0.068^{b}$ & $6.40^{\mathrm{b}}$ & $0.52^{\mathrm{b}}$ & $0.400^{c}$ & $0.502^{\mathrm{a}}$ \\
\hline Treated upper & $0.063^{\mathrm{a}}$ & $5.94^{\mathrm{b}}$ & $0.098^{\mathrm{a}}$ & $11.53^{\mathrm{a}}$ & $0.46^{\mathrm{b}}$ & $0.919^{b}$ & $0.367^{c}$ \\
\hline Treated lower & $0.063^{\mathrm{a}}$ & $6.28^{\mathrm{a}}$ & $0.117^{\mathrm{a}}$ & $10.71^{\mathrm{a}}$ & $0.63^{\mathrm{a}}$ & $1.047^{\mathrm{a}}$ & $0.415^{b}$ \\
\hline \multicolumn{8}{|c|}{ Sub-watershed (SW) $\times$ land use (LU) } \\
\hline Untreated crop & $0.041^{\mathrm{b}}$ & 6.36 & $0.064^{b}$ & $6.69^{c}$ & $0.416^{\mathrm{b}}$ & $0.470^{\mathrm{b}}$ & $0.506^{\mathrm{a}}$ \\
\hline Untreated grazing & $0.050^{\mathrm{ab}}$ & 6.24 & $0.062^{b}$ & $5.77^{c}$ & $0.466^{\mathrm{ab}}$ & $0.372^{\mathrm{b}}$ & $0.464^{\mathrm{ab}}$ \\
\hline Treated crop & $0.067^{\mathrm{a}}$ & 6.10 & $0.118^{\mathrm{a}}$ & $12.98^{\mathrm{a}}$ & $0.549^{a}$ & $1.042^{\mathrm{a}}$ & $0.374^{c}$ \\
\hline Treated grazing & $0.059^{\mathrm{a}}$ & 6.12 & $0.096^{\mathrm{a}}$ & $9.26^{\mathrm{b}}$ & $0.532^{\mathrm{a}}$ & $0.924^{\mathrm{a}}$ & $0.407^{\mathrm{bc}}$ \\
\hline \multicolumn{8}{|c|}{ Sub-watershed (SW) × soil depth (SD) } \\
\hline Untreated $0-15 \mathrm{~cm}$ & $0.036^{\mathrm{b}}$ & $6.44^{\mathrm{a}}$ & $0.082^{b}$ & $6.99^{c}$ & $0.53^{\mathrm{ab}}$ & $0.514^{c}$ & $0.522^{\mathrm{a}}$ \\
\hline Untreated $15-30 \mathrm{~cm}$ & $0.056^{\mathrm{a}}$ & $6.16^{\mathrm{bc}}$ & $0.045^{c}$ & $5.47^{c}$ & $0.36^{c}$ & $0.323^{d}$ & $0.448^{b}$ \\
\hline Treated $0-15 \mathrm{~cm}$ & $0.058^{\mathrm{a}}$ & $6.23^{b}$ & $0.122^{\mathrm{a}}$ & $13.31^{\mathrm{a}}$ & $0.59^{\mathrm{a}}$ & $1.181^{\mathrm{a}}$ & $0.394^{c}$ \\
\hline Treated $15-30 \mathrm{~cm}$ & $0.068^{\mathrm{a}}$ & $5.99^{c}$ & $0.092^{b}$ & $8.93^{b}$ & $0.49^{b}$ & $0.785^{b}$ & $0.388^{\mathrm{bc}}$ \\
\hline$P-S W \times L P$ & * & $* *$ & $* *$ & $* *$ & $* * *$ & $* * *$ & $* * *$ \\
\hline $\mathrm{P}-\mathrm{SW} \times \mathrm{LU}$ & * & ns & $* *$ & $* * *$ & * & $* * *$ & $* * *$ \\
\hline $\mathrm{P}-\mathrm{SW} \times \mathrm{SD}$ & $* *$ & $* *$ & $* *$ & $* * *$ & $* *$ & $* * *$ & $* * *$ \\
\hline
\end{tabular}

Interaction means under each heading within columns followed by different letters are significantly different from each other at $P \leq 0.05$; ${ }^{*}$ significant at $P \leq 0.05$; ${ }^{* *}$ significant at $P \leq 0.01$; ${ }^{* * *}$ significant at $P \leq 0.001$; ns non-significant; $E C$ electrical conductivity $\left(\mathrm{dS} \mathrm{m}^{-1}\right.$ ); $p H$ soil reaction (pH meter); Ex.K exchangeable potassium; Av.P available phosphorus; TN total nitrogen; $O C$ organic carbon; Ex.Na exchangeable sodium

movement into the subsurface soil layer through the process of clay migration (Tufa et al. 2019) and erosion impact on the topsoil, although trapped by conservation structures in the deposition zone.

This finding clearly showed the positive impact of SLM practices on soil displacement and deposition processes. Our finding agrees with those of Ademe et al. (2017), and Tufa et al. (2019). Ademe et al. (2017) found higher sand and silt contents, but lower clay content in the untreated watershed than the treated watershed. Moreover, Tufa et al. (2019) found no significant difference in sand particle proportions under land-use types, soil depths, and in the interaction of land-use types with soil depth. Both studies found significant differences in silt and clay proportions at different land-use types, with higher sand content on the surface and higher clay content at the subsurface of the soils. However, Demelash and Karl (2010) and Alemayehu and Fisseha (2018) presented the highest mean value of clay and the lowest mean value of sand in the non-conserved compared with the conserved landscapes. Their explanation was that tillage exposes the high clay content of subsoil to the surface, but this might be true for landscapes with deep clay soils. In highly degraded landscapes, tillage exposes the thin surface soils for erosion and leaves sand and stone behind. The watershed in the current study landscape had experienced severe soil erosion, especially at the upper slope, and had thin topsoil depth at most of the sampling locations which could be the reason for low clay content at the surface in the untreated subwatershed.

\section{Bulk density}

The higher bulk density of the untreated sub-watershed and the lower bulk density of the treated sub-watershed could be attributed to the relatively higher sand content of the soil at the untreated sub-watershed than the treated one. Soil bulk density is significantly influenced by sand content more than other soil properties (Aşkin and Özdemir 2010; Chaudhari et al. 2013). These authors found a significant correlation between bulk density and sand content, but a negative correlation between bulk density and clay content. According to Așkin and Özdemir (2010), sand content of soils is the most important soil property that determines the soil bulk density. Nevertheless, various factors such as soil texture, organic matter content, land use, and management that change the soil physical structure or organic matter content changes the bulk density (Chaudhari et al. 2013). In this study, we found a strong positive correlation $(r=$ 0.837 ) between bulk density and sand content, but a strong negative correlation $(r=-0.679)$ between bulk density and clay (Table 3). Still, the bulk density of the 
soil in both sub-watersheds is ideal for plant growth (Kaufmann et al. 2010).

Soil bulk density is also an indicator of soil compaction (Houlbrooke et al. 1997; Kaufmann et al. 2010). It indicates the status of aeration and permeability and varies with the structural conditions of the soil (Wilke 2005). Thus, compaction due to livestock trampling in the free grazing system could have contributed to the higher bulk density. The current finding agrees with the findings of Demelash and Karl (2010) and Alemayehu and Fisseha (2018) who found higher bulk density in non-conserved landscapes than the conserved landscapes. Furthermore, Tufa et al. (2019) reported higher bulk density on the surface $0-20-\mathrm{cm}$ soil depth in a cropland.

\section{Electrical conductivity}

EC is an important indicator of soil health (USDA NRCS (United States Department of Agriculture Natural Resource Conservation Services) 2012). It is a measure of the ability of the solution to carry electric current; the more dissolved ionic solutes present in the soil, the greater is its electrical conductivity (Rhoades and Corwin 1990; Provin and Pitt 2012). EC is the sum total of anions and cations, and roughly equivalent to the total dissolved solids (Rhoades and Corwin 1990).

Thus, the source of higher dissolved solutes for the higher EC in the treated sub-watershed might be from cations and anions in the higher $\mathrm{TN}$, available $\mathrm{P}$, exchangeable $\mathrm{K}$, and OC. Furthermore, the relatively higher clay particles in the treated sub-watershed and on the subsurface soil $(15-30 \mathrm{~cm}$ ) (Table 1) could have contributed to the increase of the EC of the soil, because soil particles affect the EC of the soil (Rhoades and Corwin 1990). Nevertheless, the EC of the study area is low.

\section{Soil pH}

Generally, the soils in the study area were slightly acidic; yet, it is in the preferred range for most of the agricultural practices (Alemayehu and Fisseha 2018). The pH in the study area was not affected by the interaction of the sub-watersheds and land use, but it was affected by the interaction of sub-watersheds and landscape positions, and sub-watersheds and soil depths. Accordingly, the upper landscape and the subsurface soil $(15-30 \mathrm{~cm})$ in the treated sub-watershed showed statistically lower mean values of 5.94 and 5.99 , respectively.

This finding is in line with Wolka et al. (2011) and Tufa et al. (2019). Wolka et al. (2011) found a lower pH at the treated sub-watershed than the untreated one. In the study of Tufa et al. (2019), pH was not affected by land use but a lower mean value was observed in the subsurface soil. However, Demelash and Karl (2010), Ademe et al. (2017), and Alemayehu and Fisseha (2018) found higher $\mathrm{pH}$ values on conserved plots than the non-conserved plots. Nevertheless, $\mathrm{pH}$ is affected by the constituents of organic materials (Wilke 2005). The reason for the higher $\mathrm{pH}$ at the untreated sub-watershed in the current study could be due to the higher exchangeable sodium in the sub-watershed (Table 5), linked to the parent material which is one of the factors affecting the pH of soils (Demelash and Karl 2010).

The release of hydrogen ions or by nitrification in an open system might be another reason. Ritchie and Dolling (1985) reported that $\mathrm{pH}$ increases if mineralization of organic anions to $\mathrm{CO}_{2}$ and water happen or because of the alkaline nature of organic materials. While $\mathrm{pH}$ decreases if hydrogen ions are released from the organic anions or by nitrification in an open system, no net change happens in soil $\mathrm{pH}$ if the anions released by the decaying plant materials are in the vicinity of the $\mathrm{H}^{+}$ions.

Besides, subsequent plants grown in the area and the type of fertilizer applied affect soil $\mathrm{pH}$ (Ritchie and Dolling 1985). Furthermore, historical land-use practices and subsequent soil erosion in the treated subwatershed might cause losses of more base cations before the conservation intervention are installed; and the landscapes are not restored within a short period of time (Wolka et al. 2011).

\section{Total nitrogen}

The higher TN at the treated sub-watershed compared with the untreated sub-watershed might be from two underlying sources. The first could be a decomposition of higher amount of organic materials; this is true because there was higher plant biomass production, but less exports of this biomass from the field by free grazing at the treated sub-watershed (unpublished data). The second could be an atmospheric fixation of $\mathrm{N}$ through tree lucerne plant (Mekonen et al. 2006), which was introduced as a supportive biological reinforcement of the soil bunds and terraces in the treated sub-watershed.

This finding is in agreement with Demelash and Karl (2010), Ademe et al. (2017), and Alemayehu and Fisseha (2018), who found significantly higher TN at the conserved plots than the non-conserved plots. Furthermore, Tufa et al. (2019) found higher TN at forest land than the grazing land, and it decreased as soil depth increased.

\section{Available phosphorus}

The higher soil Av.P at the treated sub-watershed could be attributed to the release of phosphorus from the decomposition of organic materials. The higher Av.P in the croplands could be associated to the adequate aeration brought about by tillage as $\mathrm{P}$ release is faster in 
good aerated soils (Brdjanovic et al. 1998; Kwabiah et al. 2001).

This finding is in agreement with other researchers (Ademe et al. 2017; Aytenew and Kibret 2016; Tufa et al. 2019). Ademe et al. (2017) found higher P at conserved landscape than the non-conserved one, Aytenew and Kibret (2016) found higher P on cropland compared with the adjacent grassland, and Tufa et al. (2019) reported higher P on the surface $0-20 \mathrm{~cm}$ than the subsurface soil.

\section{Exchangeable potassium}

The higher Ex.K at the treated lower landscape positions could be due to the erosion from the top and deposition of $\mathrm{K}$ mineral down the slope. Conservation practices in the treated sub-watershed might have contributed to the higher Ex.K through increasing organic matter, improving the clay content, and reducing leaching of weathered $K$ as opposed to the untreated sub-watershed in the study area. Potassium availability is highly correlated with clay content and the OC of soils (Zhang et al. 2009).

The potassium content of soils depends on various factors such as clay mineral types, $\mathrm{pH}$, soil organic matter, aluminium hydroxide, soil moisture status, cation exchange capacity, fertilizer application and tillage system (Zhang et al. 2009). Furthermore, weathering of potassium-containing minerals and leaching of weathered potassium minerals also affect soil $\mathrm{K}$ content (Schroedeer 1980). Our results agree with Ademe et al. (2017) who found higher $\mathrm{K}$ values in the treated landscapes and the downslope parts in contrast to the untreated landscapes and upper parts; however, it differs from the findings of Tufa et al. (2019) who reported that soil $\mathrm{K}$ content was affected by land use but not by soil depth.

\section{Soil organic carbon}

The higher $\mathrm{OC}$ content in the lower section of the treated sub-watershed and at the surface $0-15 \mathrm{~cm}$ of the cropland could be due to the accumulation of relatively higher organic matter (Ademe et al. 2017). Furthermore, higher $\mathrm{OC}$ at the lower section of the treated subwatershed (Table 5) can be explained by the transport of organic materials from upper slope to the lower slope through runoff and erosion as well as relatively better moisture availability in the lower landscape to favor decomposition of organic materials and release of OC (Alemayehu and Fisseha 2018). The soil moisture content was higher in the lower landscape compared with the upper section (unpublished data). Our results agree with the findings of Demelash and Karl (2010) and Ademe et al. (2017), who reported higher organic matter and $\mathrm{OC}$ in the treated watersheds than the untreated ones, and at the lower landscape positions than the upper landscape positions.

\section{Conclusions}

Soil bulk density, sand and silt proportions, and $\mathrm{pH}$ were significantly higher in the untreated sub-watershed, while clay content, EC, N, P, K, and OC were significantly higher in the treated sub-watershed. Landscape positions did not show statistical differences for most of the selected soil chemical properties, but land-use types affected Av.P and OC, with higher mean values for croplands than grazing lands, which could be due to accumulation and decomposition of organic materials, and the contribution of conservation structures in trapping transported organic materials by runoff from the upper slopes. Therefore, watershed-based SLM interventions at Geda watershed were effective in improving the soil physicochemical properties and restoration of soil ecosystem functions. Thus, it is of paramount importance to enhance the awareness of the community in maintaining watershed management intervention options, including adequate grazing management to reduce landscape degradation and increase the accumulation of organic matter for improving soil health and thus ecosystem balance.

\section{Abbreviations}

ANOVA: Analysis of variance; SLM: Sustainable land management: SLMP: Sustainable Land Management Program; SWC: Soil and water conservation; USDA NRCS: United States Department of Agriculture Natural Resource Conservation Services; USEPA: United States Environmental Protection Agency

\section{Acknowledgements}

We highly appreciate the help of Dr. Wondosen Tena, Dr. Adamu Molla, Dr. Wuletaw Abera, Mr. Getahun Agumas, Mr. Lisanu Getaneh, and Mr. Getaneh Shegaw in the course of this research work. We greatly acknowledge the editors of this manuscript.

\section{Authors' contributions}

All authors contributed to the different stages of this study. MA, LT, and KM were involved in the design of the study, supervised the progress, and provided comments on the manuscript. HT designed the study, collected and analyzed the samples, interpreted the data, and wrote the draft manuscript. JR and DS supervised the work and provided comments on the manuscript. JR reviewed the language. All authors read and approved the final manuscript.

\section{Authors' information}

Hailu Terefe is a lecturer and researcher at the Department of Plant Science, Debre Berhan University, Ethiopia. Hailu Terefe attended his BSC at the Department of Crop and Horticultural Science, Mekelle University, Ethiopia, and his MSc at the Department of Plant Science, Wageningen University and Research Center, The Netherlands. Currently, he is a PhD student at the Center for Environmental Science, Addis Ababa University, P.O. Box 1176, Addis Ababa, Ethiopia. Mekuria Argaw is an associate professor in

Environmental Science at the Center for Environmental Science, Addis Ababa University, Ethiopia. Lulseged Tamane is a scientist in landscape ecology and resource management at the International Center for Tropical Agriculture. Kindu Mekonnen is a crop-livestock systems scientist at ILRI. John Recha and Dawit Solomon are soil scientists at ILRI. 


\section{Funding}

This research was undertaken with support from Africa RISING, a program financed by the United States Agency for International Development (USAID) as part of the United States Government's Feed the Future Initiative. The content is solely the responsibility of the author/s and does not necessarily represent the official views of USAID or the U.S. Government or that of the Africa RISING program. Africa RISING is aligned with research programs of the CGIAR.

\section{Availability of data and materials}

The dataset and materials used in this manuscript are available and can be shared whenever necessary. The data was generated by the authors from the field sample collection, processing, and laboratory analysis.

\section{Ethics approval and consent to participate}

Not applicable.

\section{Consent for publication}

Not applicable.

\section{Competing interests}

The authors declare that they have no competing interests.

\section{Author details}

${ }^{1}$ Center for Environmental Science, College of Natural Science, Addis Ababa University, P.O. Box 1176, Addis Ababa, Ethiopia. ${ }^{2}$ International Center for Tropical Agriculture (CIAT), P.O. Box 5689, Addis Ababa, Ethiopia. ${ }^{3}$ International Livestock Research Institute (ILRI), P.O. Box 5689, Addis Ababa, Ethiopia. ${ }^{4}$ International Livestock Research Institute (ILRI), P.O. Box 30709, Nairobi 00100, Kenya.

Received: 4 October 2019 Accepted: 20 January 2020

Published online: 09 March 2020

\section{References}

Ademe Y, Temesgen K, Alemayehu M, Toyiba S (2017) Evaluation of the effectiveness of soil and water conservation practices on improving selected soil properties in Wonago district, Southern Ethiopia. J Soil Sci Environ Manage 8:70-79

Adimassu Z, Mekonnen K, Yirga C, Kessler A (2014) Effect of soil bunds on runoff, soil and nutrient losses, and crop yield in the central highlands of Ethiopia. Land Degrad Dev 25:554-564

Adimassu Z, Simon L, Robyn J, Wolde M, Tilahun A (2017) Impacts of soil and water conservation practices on crop yield, runoff, soil loss and nutrient loss in Ethiopia: review and synthesis. Environ Manag 59:87-101

Alemayehu T, Fisseha G (2018) Effects of soil and water conservation practices on selected soil physico-chemical properties in Debre-Yakob Micro-Watershed, Northwest Ethiopia. Ethiopia J Sci Technol 11:29-38

Amare T, Birru Y, Hans H (2013) Effects of "Guie" on soil organic carbon and other soil properties: a traditional soil fertility management practice in the central highlands of Ethiopia. J Agric Sci 5:237-244

Ashagrie T (2009) Modeling rainfall, runoff and soil loss relationships in the northeastern highlands of Ethiopia, Andit Tid watershed. MSc thesis. New York: Cornell University

Aşkin T, Özdemir N (2010) Soil bulk density as related to soil particle size distribution and organic matter content

Ayalew A (2011) Construction of soil conservation structures for improvement of crops and soil productivity in the Southern Ethiopia. J Environ Earth Sci 1:21-29

Aytenew M, Kibret K (2016) Assessment of soil fertility status at Dawja watershed in Enebse Sar Midir district, Northwestern Ethiopia. Int J Plant Soil Sci 11:1-13

Berhanu AK, Teddy GB, Dinaw DM, Meles BN (2016) Soil and water conservation practices: economic and environmental effects in Ethiopia. Glob J Agric Econ Econometrics 4:169-177

Brdjanovic D, Slamet A, Vanloosdrecht MCM, Hooijmans CM, Alaerts GJ, Heijnen JJ (1998) Impact of excessive aeration on biological phosphorus removal from wastewater. Water Res 32:200-208

Chaudhari PR, Ahire DV, Ahire VD, Chkravarty M, Maity S (2013) Soil bulk density as related to soil texture, organic matter content and available total nutrients of Coimbatore soil. Int J Sci Res Publ 3:1-8
Demelash M, Karl S (2010) Assessment of integrated soil and water conservation measures on key soil properties in South Gonder, North-Western Highlands of Ethiopia. J Soil Sci Environ Manage 1:164-176

Descheemaeker K, Jan N, Joni R, Jean P, Mitiku H, Dirk R, Bart M, Jan M, Seppe D (2006) Sediment deposition and pedogenesis in exclosures in the Tigray highlands, Ethiopia. Geoderma 132:291-314

Dessalegn CD, Christian DG, Assefa DZ, Tigist YT, Menelik G, Solomon A, Fasikaw AZ, Essayas KA, Seifu AT, Tammo SS (2015) Impact of conservation practices on runoff and soil loss in the sub-humid Ethiopian Highlands: the Debre Mawi watershed. J Hydrol Hydromechanics 63:210-219

Ebabu K, Tsnekawa A, Haregeweyn N, Adgo E, Meshesha DT, Aklog D, Masunaga T, Tsubo M, Sultan D, Fenta AA, Yibeltal M (2017) Analyzing the variability of sediment yield: a case study from paired watersheds in the upper Blue Nile basin, Ethiopia. Geomorphology 303:446-455

Gashaw T (2015) Soil erosion in Ethiopia: extent, conservation efforts and issues of sustainability. Palgo J Agric 2:38-48

Gashaw T, Amare B, Hagos GS (2014) Land degradation in Ethiopia: causes, impacts and rehabilitation techniques. J Environ Earth Sci 4:98-104

Gashaw T, Taffa T, Mekuria A (2017) Erosion risk assessment for prioritization of conservation measures in Geleda watershed, Blue Nile basin, Ethiopia. Environ Syst Res 6:1-14

Gebretsadik ZM (2013) A holistic approach to the restoration of degraded natural resources: a review and synthesis. Res J Agric Environ Manage 2:058-068

Haldar A, Sakar D (2005) Physical and chemical method in soil analysis: fundamental concepts of analytical chemistry and instrumental techniques. New Delhi: New Age International (P) Ltd.

Haregeweyn N, Ademnur B, Atsushi T, Mitsuru T, Derege TM (2012) Integrated watershed management as an effective approach to curb land degradation: a case study of the Enabered watershed in northern Ethiopia. Environ Manag 50:1219-1233

Hishe S, Lyimo J, Bewket W (2017) Soil and water conservation effects on soil properties in the Middle Silluh Valley, northern Ethiopia. Int Soil Water Conserv Res 5:231-240

Houlbrooke DJ, Thom ER, Chapman R, CDA ML (1997) A study of the effects of soil bulk density on root and shoot growth of different ryegrass lines. N Z J Agric Res 40:429-435

Kaufmann M, Tobias S, Schulin R (2010) Comparison of critical limits for crop plant growth based on different indicators for the state of soil compaction. J Plant Nutr Soil Sci 173:573-583

Kirui OK, Mirzabaev A (2015) Costs of land degradation in Eastern Africa. International conference of agricultural economists, on the theme: agriculture in an interconnected world held on 29th May 2010, Italy

Kwabiah AB, Stoskopf NC, Voroney RP, Palm CA (2001) Nitrogen and phosphorus release from decomposing leaves under sub-humid tropical conditions. Biotropica 33:229-240

Masebo N, Abdellkadir A, Mohammed A (2014) Evaluating the effect of agroforestry based soil and water conservation measures on selected soil properties at Tembaro district, SNNPR, Ethiopia. Direct Res J Agric Food Sci 2:141-146

Mekonen K, Glatzel G, Tadesse Y, Yosef A (2006) Tree species screened on nitosols of central Ethiopia: biomass production, nutrient contents and effect on soil nitrogen. J Trop For Sci 18:173-180

Mekuria W, Menale W, Tadele A, Asmare W, Tesfaye F, Birru Y (2018) Restoration of degraded landscapes for ecosystem services in North-Western Ethiopia. Heliyon 4:e00764

Mekuria W, Veldkamp E, Corre MD, Haile M (2011) Restoration of ecosystem carbon stocks following exclosure establishments in communal grazing lands in Tigray, Ethiopia. Soil Sci Soc Am J 75:246-256

Mulugeta D, Karl S (2010) Assessment of integrated soil and water conservation measures on key soil properties in South Gonder, North-Western Highlands of Ethiopia. J Soil Sci Environ Manage 1:164-176

Olsen SR, Cole CV, Watanabe FS, Dean LA (1954) Estimation of available phosphorus in soils by extraction with sodium bicarbonate. USDA Circular No. 939. US Gov. Print. Office, Washington, D.C.

Paetz A, Wilke BM (2005) Soil sampling and storage. In: Margesin R, Schinner F (eds) (2005) Manual of soil analysis: monitoring and assessing soil bioremediation (3). Berlin: Springer-Verlag

Provin T, Pitt JL (2012) Managing soil salinity. Texas A \& M. Agrilife extension E-60

Rhoades JD, Corwin DL (1990) Soil electrical conductivity: effects of soil properties and application to soil salinity appraisal. Commun Soil Sci Plant Anal 21:837-860 
Ritchie GSP, Dolling PJ (1985) The role of organic matter in soil acidification. Aust J Soil Res 23:569-576

Schroedeer D (1980) Structure and weathering of potassium containing minerals. Potassium in the soil/plant root system. International potash institute $\mathrm{CH}-$ 3084 Worblaufen-Bern, Switzerland

Tamene $L$ (2017) Integrated watershed management interventions monitoring in Geda watershed in the Ethiopian Highlands. Factsheet Geda

Tamene L, Mekonnen K, Tesfaye Y (2015) Processes of managing collaborative model watersheds in Africa RISING sites: landscape/watershed visit organized for Africa RISING team members of the West Africa, Southern and East Africa projects

Thomas R, Reed M, Clifton K et al (2018) A framework for scaling sustainable land management options. Land Degrad Dev 29:3272-3284

Tiki L, Gonfa K, Alemayehu W (2016) Effectiveness of watershed management interventions in Goba district, southeastern Ethiopia. Int J Agric Sci 6:1133-1140

Tor-Gunnar V, Yibabe T, Kjell BE (1999) Effects of stone terracing on available phosphorus and yields on highly eroded slopes in Tigray, Ethiopia. J Sustain Agric 15:61-74

Tufa M, Asmare M, Wondwosen T (2019) Effects of land-use types on selected soil physical and chemical properties: the case of Kuyu District, Ethiopia. Eur J Soil Sci 8:94-109

USDA NRCS (United States Department of Agriculture Natural Resource Conservation Services) (2012) Soil electrical conductivity: soil health. Guide for educator

USEPA (United State Environmental Protection Agency) (2002) Guidance on choosing a sampling design for environmental data collection. Office of Environmental Information, Washington, DC, p 20460

Van Reeuwijk LP (2002) Procedures for soil analysis. In: International soil reference and information center. Technical paper 9, 6th edn

Wilke BM (2005) Determination of physical and chemical soil properties. In: Margesin R, Schinner F (eds) Manual of Soil Analysis: monitoring and assessing soil bioremediation (3). Springer-Verlag, Berlin

Wolka K, Moges A, Yimer F (2011) Effects of level soil bunds and stone bunds on soil properties and its implications for crop production: the case of Bokole watershed, Dawuro zone, Southern Ethiopia. Agric Sci 2:357-363

Zhang HM, Xu MG, Zhang WJ, Hex H (2009) Factors affecting potassium fixation in seven soils under 15-year long-term fertilization. Chin Sci Bull 54:17731780

\section{Publisher's Note}

Springer Nature remains neutral with regard to jurisdictional claims in published maps and institutional affiliations.

\section{Submit your manuscript to a SpringerOpen ${ }^{\circ}$ journal and benefit from:}

- Convenient online submission

- Rigorous peer review

- Open access: articles freely available online

High visibility within the field

- Retaining the copyright to your article

Submit your next manuscript at $\boldsymbol{\nabla}$ springeropen.com 